\title{
Development of Online Learning Based on Schoology on Digital Communication Simulation Subjects in State Vocational High School 7 in Batam
}

\author{
Taufiqurrohman $^{1}$, Nizwardi Jalinus ${ }^{1}$, Sukardi ${ }^{1}$, Adyanata Lubis ${ }^{2}$, B.Herawan Hayadi ${ }^{3}$ \\ ${ }^{1}$ Master of Technology and Vocational Education Master Program, Faculty of Engineering, \\ Padang State University \\ ${ }^{2}$ STIKIP Rokania, Riau Indonesia \\ ${ }^{3}$ Universitas Pasir Pengaraian, Riau Indonesia \\ ${ }^{1}$ TEGREXS@gmail.com
}

\begin{abstract}
Based on the initial test, the learning outcomes of students in simulation and digital communication subjects at state vocational school 7 in Batam, many of them are still below the minimum passing limit. After the research was conducted, it was found that it was possible that one of the causes was because the learning media used was less attractive. So that students are not motivated and left behind to take part in classroom learning. The researcher developed the media of schoologybased learning in simulation subjects and digital communication in the hope that after this development, learning media will be valid, practical, and effective for management information systems courses. Research and development of instructional media were carried out with the ADDIE research model. To find out the validity, practicality, and effectiveness of the use of learning media validation, practicality test, and effectiveness test. Based on the results of the data analysis, the validity of the learning media developed has fulfilled the material and media aspects with "valid" results according to the values of Aiken's V. Data on practicality of learning media is taken through the results of filling in practicality questionnaires filled by students and teachers of simulation subjects and digital communication. The response from the instructor and students was very high practicability category, so it can be concluded that the learning media developed practically were used by teachers and students with very high practicality categories. Based on the results of learning before the use of learning media developed it was found that out of 36 students of class X majoring in banking 1 obtained an average value of 65.35 , then we call the pre-test. Then after the application of the development of learning media, a post-test assessment was conducted with an average score of 80.28. This shows that there is an increase in student learning outcomes between before and after using learning media. This is also proven through the gain score test where the value is 0.43 with the medium category. So, it can be concluded that learning using media can be said to be effective in improving learning outcomes.
\end{abstract}

Keywords: Online Learning, Vocational High School, Education. 


\section{INTRODUCTION}

The curriculum applied at the state Vocational High School 7 in Batam is the 2013 curriculum. With the application of the curriculum, there are subject changes, namely subjects in computer skills and information management to digital simulation and communication [1], [2].

Digital simulation and communication are included in group $\mathrm{C} 1$, which is only taught in class x. Digital simulation and communication are taught so students can explore ideas to solve problems related to products or services, find alternative solutions, and communicate in the form of collaboration and sharing so that digital simulations and communication become one of the life skills of Vocational High School students [3].

Through observation at state Vocational High School 7 in Batam, the learning model used in digital communication simulation subjects for class $\mathrm{x}$ banking majors is a conventional learning model. In this learning process, several problems were encountered, namely a low understanding of the mastery of subject matter by students. Based on interviews with simulation subject teachers and digital communication problems were found including: First, limited learning media, namely in the form of power points and books downloaded from the internet. Second, the teacher does not have a reference source other than books on the internet. Because digital communication and simulation subjects are still new when implementing the 2013 curriculum. Third, the use of information technology, especially the internet in learning is not optimal, even though schools provide wifi facilities and provide opportunities for students to search for material, but students tend to access social media sites like Facebook, which does not necessarily have anything to do with the material. Fourth, the material density, so that not all material is discussed one by one in class [4], [5].

A careful plan carried out by the teacher in teaching at this time is to explain directly the learning material contained in the teaching material, then discuss, then give the training assignment so that the form of learning with a careful plan feels less appropriate for achieving learning goals.

Regarding the problem above, it is necessary to have a learning approach pattern that can overcome these needs, for example, e-learning is made as a means of communication between students and teachers, as well as a means of delivering learning material online. So that teachers and students not only rely on face-to-face communication, but with online facilities can be a bridge of communication, interaction, and consultation outside of lesson hours.

The online combination is a learning model that combines conventional learning with information technology that is written on a website so that students can freely access and download material and can make it easier for teachers to monitor student activity starting from the activity of opening pages, correcting quizzes, and providing remedies.

Kim [6] explained that online is not just an alternative to carrying out learning. But online has become the main tool in achieving global competitiveness. With this opinion, it is best not to immediately abandon the face-to-face learning approach that has been running, but online media can be used as a supplement, complement, and replacement of existing learning approaches.

Implementation of an online or E-learning functions as a supplement, if it is used as an addition to the main material that must be mastered by students, also, students have the freedom to choose, whether to use electronic learning material or not. In this case, there is no necessity for students to access material electronically because the material is added to enrich students' knowledge of the main material. E-learning is said to be useful as a compliment if it is used to complete face-to-face learning. The goal is for students to more easily understand the learning 
material discussed in the classroom. It is said replacement if e-learning functions as a substitute for face-to-face learning in the classroom. With this replacement, students can easily learn by adjusting their time and other activities.

One of the free web-based educational applications that allow teachers to teach students online is schoology. Schoology adopts Facebook as an interface and features for the convenience of users. Students only access www. Schoology.com on a computer or smartphone, and can download schoology on the PlayStore or AppStore with their smartphone [7].

Schoology is one of several LMS that provides facilities to teachers and students to interact with each other in a learning environment through online social networks. LMS is a management system that allows teachers to provide teaching material, organize the learning process, and evaluate the learning process [8].

Online learning contained in the web can guide students to learn independently because learning can shift from teacher-oriented learning (teacher centered) to student-oriented learning. Uskov [9] revealed that learning with the help of a website can make learning centered on students. Students are independently responsible for learning. Online learning will make active students play a role in learning. Students will try and take the initiative in planning and searching for material independently. So using schoology-based e-learning can enrich the value of conventional learning and strengthen conventional learning models through content enrichment and the development of educational technology[10], [11].

Based on the explanation, an innovative learning strategy is needed that can support and strengthen the material understanding by students towards digital simulation and communication learning delivered conventionally, by utilizing web-based network technology namely online using schoology applications. It is expected that through the online approach, so that the learning atmosphere becomes effective, and so that it motivates students in learning activities and gets maximum results[12].

\section{LITERATURE REVIEW}

The teaching and learning process in education is a major part of making the output of students. Learning that runs effectively and efficiently will certainly be comparable to the results be achieved. The process, sought by the teacher systematically, starts from the planning, implementation, and evaluation of learning outcomes.

In Permendikbud No. 103 of 2014 stated that the learning and teaching process is an interaction between students, between educators and students and learning resources in the learning environment.

According to Gagne defines learning as a process of changing behavior, which arises as a result of experience [13]. Surya, learning is a process carried out by individuals to obtain changes in new behavior as a whole, as the experience of the individual itself in interaction with the environment [14]. Learning is a process of permanent change of behavior from the podium not knowing to know, and from not understanding to understanding, from being less skilled to be more skilled and from old habits to new habits, and beneficial to the environment and the individual itself [15].

\section{METHOD}

The model of building learning devices compiled in this study refers to the type of development of the ADDIE model learning design. The design model of the ADDIE learning system is simple and can be done in stages [16]. The ADDIE model is widely applied in learning 
environments that have been designed according to the learning objectives. According to Khao Yao Tung [17], ADDIE learning device contains five stages, namely analyzing, designing, developing, implementing, and evaluating.

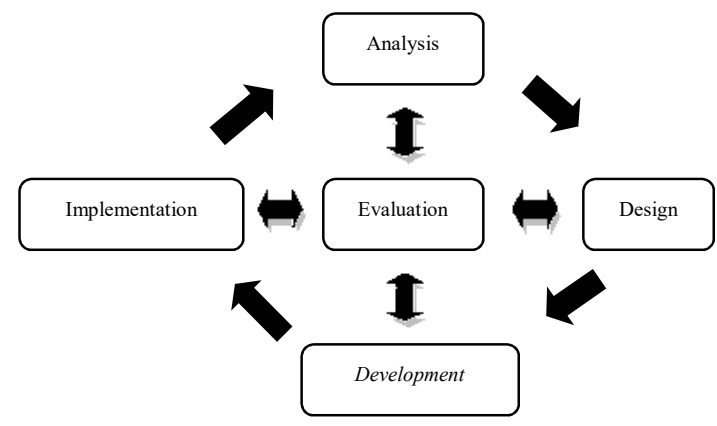

Figure 1. ADDIE model and stages

\section{RESULT AND DISCUSSION}

This compilation activity is in the form of a media display design that includes parts of Home, Courses Material, Groups, and Resources.

1. Home contains instructions for use as well schoology usage feature

2. Courses Material, contains material arranged as learning material.

3. Groups contains about the division of classes or groups arranged by the teacher

4. Resource contains additional teaching materials that support learning.

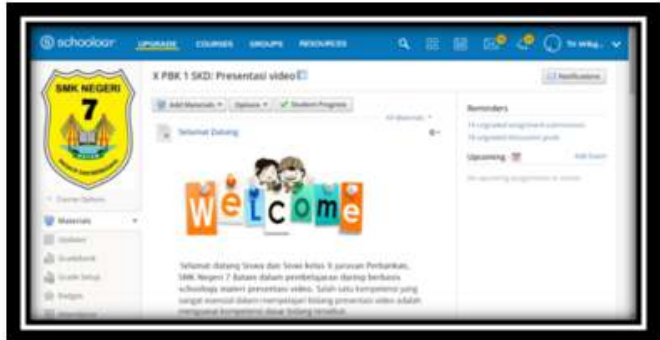

Figure 2. Display of welcome schoology

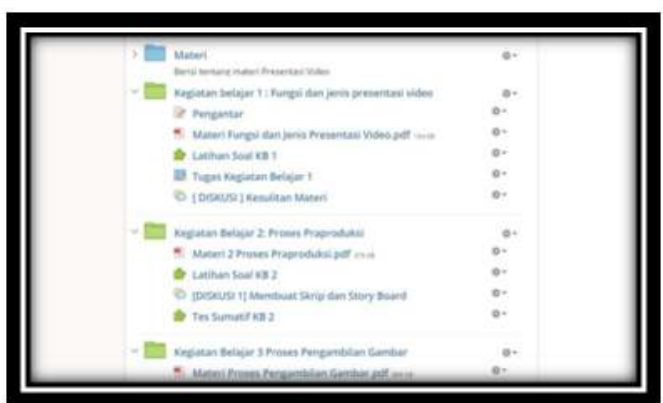

Figure 4. Display material menu

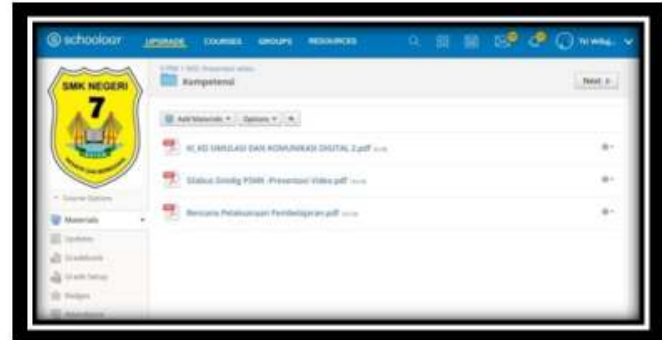

Figure 3. Display of Competence

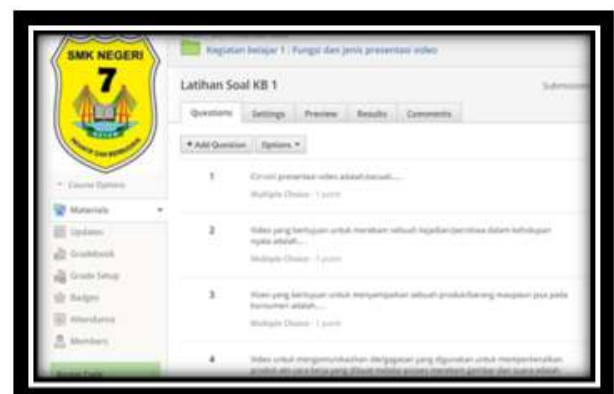

Figure 5. Schoology Practice Questions 


\section{CONCLUSION}

Based on the results of research and discussion, conclusions can be taken as follows: The development of school-based online learning media for the subject matter of video presentations for class $\mathrm{X}$ vocational high schools is done through five stages, namely:

a. Analysis

Curriculum analysis

The material developed in schoology-based online media is video presentations for class $\mathrm{X}$ vocational high schools with basic competencies: designing pre-production stage documents, analyzing video production, animation and or digital music, evaluating post-video production, animation and or digital music.

Analysis of student characteristics

Students of state Vocational High School X grade in Batam, on average have reached the formal operational stage that is capable of abstract thinking.

\section{Analysis of computer technology}

Online learning (in networks) developed in the media is online schoology. Schoology has several advantages that are suitable for developing media with video presentation material.

b. Design

The preparation of the media framework that will be developed is arranged in initial design of media.

\section{c. Development}

Product manufacturing is done by developing designs using online schoology. The end of making this product, the media was reviewed by media experts and material experts to be evaluated as a revised guideline with validity scores by media experts reaching 0.85 which included very valid categories and validity scores by material experts reaching 0.88 which included categories very valid.

d. Implementation

Product testing was conducted in the field in learning video presentations for banking students 1 in class $\mathrm{X}$ as well as simulation and digital communication subject teachers in the state of Vocational High School 7 in Batam

\section{e. Evaluation}

Evaluation is carried out based on the results of trials in the field.

In this development research, it produces a learning media that is valid, practical and effective, in simulation and digital communication subjects this is proven because this learning media has undergone trials of validity, practicality, and effectiveness which is done on the validator, and the instructor, in this case, the teachers and students.

\section{REFERENCES}

[1] Y.-Y. Wang and C.-C. Lu, "Using weibull density function in importance sampling for digital communication system simulation," IEE Proc. I Commun. Speech Vis., vol. 140, no. 2, p. 163, 1993.

[2] T. Mathumisaranon and P. Chayratsami, "MATLAB GUI for digital communication system with tone jamming," in Proceedings of 2013 IEEE International Conference on Teaching, Assessment and Learning for Engineering (TALE), 2013, no. August, pp. 589-592. 
[3] C. Zhou, E. Cheng, W. Su, and H. Sun, "Adaptive design of digital FIR filter for beamforming with Its application in PSK UWA communication," in IEEE ICCA 2010, 2010, no. 2, pp. 1915-1918.

[4] P. G. Flikkema, G. B. Shyam, and J. Hariprasad, "Template-Based Simulation In Digital Wireless Communication," pp. 406-410.

[5] J. M. de la Rosa, "Using behavioral modeling and simulation for learning communication circuits and systems," in Proceedings of the 2012 IEEE Global Engineering Education Conference (EDUCON), 2012, pp. 1-7.

[6] B. Kim, H. Park, and Y. Baek, "Not just fun, but serious strategies: Using metacognitive strategies in game-based learning," Comput. Educ., vol. 52, no. 4, pp. 800810, May 2009.

[7] O. A. D. Almaghlouth, "Investigate the Utilisation of Web 2.0 Applications: A Case Study of a Marketing Teacher and His Web-Enhanced Course Building on E-Learning Concepts at One University in KSA," in 2015 Fifth International Conference on eLearning (econf), 2015, pp. 153-160.

[8] K. A. Rahman, S. A. M. Ghazali, and M. N. Ismail, "The effectiveness of learning management system (LMS) case study at Open University Malaysia (OUM), Kota Bharu Campus," J. Emerg. Trends Comput. Inf. Sci., vol. 2, no. 2, pp. 73-79, 2010.

[9] V. Uskov, "Student-centered learning in online and blended education on computer information systems," in 33rd Annual Frontiers in Education, 2003. FIE 2003., vol. 1, p. T4F_17-T4F_22.

[10] Y. Sonmez, T. Tuncer, H. Gokal, and E. Avci, "Phishing web sites features classification based on extreme learning machine," in 2018 6th International Symposium on Digital Forensic and Security (ISDFS), 2018, pp. 1-5.

[11] N. A. Radzi, S. Sivapalan, W. F. bt Wan Ahmad, and A. H. Abdullah, "Incorporation of multimedia approaches to literature online via e-learning for foundation level literature courses: The case of a private institution of higher learning in Malaysia," in 2010 International Symposium on Information Technology, 2010, pp. 920-923.

[12] I.-L. Chung, C.-M. Chou, C.-P. Hsu, and D.-K. Li, “A programming learning diagnostic system using case-based reasoning method," in 2016 International Conference on System Science and Engineering (ICSSE), 2016, pp. 1-4.

[13] E. Kosasih, Strategi belajar dan pembelajaran Implementasi Kurikulum 2013. Bandung: Yrama Widya, 2014.

[14] M. Hosnan, Pendekatan saintifik dan kontekstual dalam pembelajaran abad 21: Kunci sukses implementasi kurikulum 2013. Bandung: Ghalia Indonesia, 2014.

[15] M. P. Trianto, Mendesain Model Pembelajaran Inovatif-Progresif. Jakarta: Kencana, 2009.

[16] I. Koneru, "Addie: Designing web-enabled information literacy instructional modules," Desidoc J. Libr. Inf. Technol., vol. 30, no. 3, pp. 23-34, 2010.

[17] K. Y. Tung, Pembelajaran dan perkembangan belajar. Jakarta: PT Indeks, 2016. 